UDC 340.1

DOI https://doi.org/10.32782/2524-0374/2020-3/10

\title{
INTERNET AND DEMOCRACY
}

\author{
ІНТЕРНЕТ ТА ДЕМОКРАТІЯ
}

\author{
Petrovych A.I., 5th year Student \\ of the Faculty of International Law \\ Yaroslav Mudryi National Law University
}

It is impossible to imagine a modern civilised world without the Internet, which gives everyone, regardless of national borders, an opportunity to find, receive and spread information and express themselves. All processes of the world order move to a new level and find their reflection in the virtual world. Political and social institutions play an important role in shaping and developing new technologies. There is also a globalization of the political sphere with the use of information technologies, which leads to the creation of a transnational media Empire that creates reality for itself and manipulates the consciousness of the masses at its own discretion. Because of the multifaceted nature of the Internet and democracy, it is necessary to consider the various causal relationships that link technological change, political communication systems, and democratic governance. The Internet imposes a new communication infrastructure on existing communication processes. It can play an important role in strengthening representative democracy, as it allows for the integration of deliberative elements into the democratic system. The Committee of Ministers of the Council of Europe speaks of the need to promote active public participation in the use of the Internet and free communication.

In this paper, the author reveals the concept of "democracy" and the purpose of the internet creation, how democracy develops in the conditions of transition of many political processes, as well as the solution of state problems in a new dimension of the Internet. In the process, the author describes new opportunities which Internet provides for the development of democracy, the author also explains how the Internet affects the development of a legal society and the freedom of speech within it. The article takes several countries for comparison and compares the mechanisms of influence on citizens through information and communication technologies, as well as examines the legal mechanisms of e-democracy, which is designed to increase the level of participation, transparency, accountability and representation of public opinion. In addition, the positive and negative sides of the ongoing processes, the opinion of scientists and of the author herself are clarified.

Key words: democracy, internet, electronic democracy, freedom of speech.

Неможливо уявити сучасний цивілізований світ без Інтернету, який дає кожній людині, незважаючи на національні кордони, можливість знайти, отримати, поширити індоормацію і виражати свої думки. Всі процеси світоустрою переходять на новий рівень і знаходять своє відображення у віртуальному світі. Політичні та соціальні інститути відіграють важливу роль у формуванні та розвитку нових технологій. Відбувається в тому числі глобалізація політичної сфери з використанням інформаційних технологій, що призводить до створення транснаціональної медіа-імперії, яка створює реальність під себе і маніпулює свідомістю мас на власний розсуд. Через багатогранну природу Інтернету і демократії, необхідно розглядати різні причинно-наслідкові зв'язки, що зв'язують технологічні зміни, системи політичної комунікації і демократичного управління. Інтернет накладає нову комунікаційну інфраструктуру на існуючі комунікаційні процеси. Він може відігравати важливу роль у зміцненні представницької демократії, оскільки дозволяє впроваджувати дорадчі елементи в демократичну систему. Комітет міністрів Ради Європи говорить про необхідність сприяння активній участі громадськості у використанні мережі Інтернет і вільному спілкуванню.

У даній роботі автор розкриває поняття “демократії” і мету створення Інтернету, як розвивається демократія в умовах переходу багатьох політичних процесів, а також вирішення державних проблем у новій площині - Інтернет. У процесі роботи автор описує, які нові можливості надає Інтернет для розвитку демократії, а також як Інтернет впливає на розвиток правового суспільства і свободу слова в ньому. У статті беруться кілька країн для порівняння і зіставляються механізми впливу на громадян через інфрормаційно-комунікаційні технології, а також розглядаються правові механізми електронної демократії, яка покликана підвищити рівень участі, прозорість, підзвітності та представництва думки населення. Крім цього, з'ясовуються позитивні і негативні сторони процесів, що відбуваються, думки вчених і безпосередньо автора.

Ключові слова: демократія, інтернет, електронна демократія, свобода слова.

\section{Introduction}

The concept of "democracy" as such originated in the 6th century BC. It first appeared in ancient Greek political and philosophical thought in the city-state of Athens during classical antiquity. Democracy translated from Greek (demokratia <demos - people + kratos - power) means the power of the people. The Internet came into existence in the 1960s (25 centuries after democracy) as a way for government researchers to share information. What connects them and how these concepts can be correlated?

Currently, power, its political structures and institutions are undergoing significant transformations. The state needs new technologies of power and management. Efficiency, dynamics and general accessibility of the Internet make it possible to effectively influence the spiritual life of society, the consciousness of the widest masses of the people.

The issue of the influence of the Internet and of other information and communication technologies on democracy was studied by such scientists as Bykov A., Kabanov Y., Romanov B., Grachev M., Madatov A., Magomedov A., Rheingold H., Weare C. et al.

The role of the Internet in the development of democracies is ambiguous, and technological progress can at help of harm the development of society. What new opportunities does the Internet provide for the development of democracy? How does the Internet influence the development of a legal society? I will try to disclose these questions below.

\section{Main part}

In the 1990s, the Internet was a place of free communication and data exchange; its development was associated with a positive impact on the development of democracy around the world. The Internet, optimists believed, is better developed organically in democracies, and in autocracies, influencing governments, it promotes democratization. That was at the dawn of the Internet, but today the situation is different, according to a study of Interaction between the Internet and the Political Regime [1], conducted by Yuri Kabanov and Bogdan Romanov of the HSE. The authors analyzed international indicators of Internet development (population coverage according to the World Bank) and the dynamics of government regimes from 1995 to 2015. Today, the Internet is best developed in two groups of countries: in strong consolidated autocracies like Bahrain, Qatar and the UAE and in liberal democracies like Norway, Denmark and Germany. The Internet today is just a toolkit, the researchers conclude: it can be in demand in virtually any political environment and rapidly develop in any mode, it is not the technology itself and the depth of its penetration that is important, but what Internet contents.

Amodern vision of the procedural foundations of democracy cannot ignore the technical development of the modern 
society. The emergence and the growing role of electronic systems in the structure of mass communications inevitably brought to life the ideas of teledemocracy ("cyberocracy"). In this case, an existence of procedures traditional for democracy is inextricably linked with the level of technical equipment of the authorities and civil structures with interactive systems (TV, Internet) during elections, referenda, plebiscites, etc. This virtualization of politics poses a new problems in the field of ensuring the integration of society, establishing relations with new communities of citizens (with or without such technical means), changing forms of government control over the public, and, conversely, removing a number of restrictions on political participation, assessing the qualifications of popular opinion, ways of accounting, etc.

Information and communication technologies (ICT) provide an opportunity to move to a modern model of democracy, in which access to information, the possibility of direct participation in the management of state and non-state structures will be available to all citizens who will not need traditional national media. Such a model is called "e-democracy", which in a political science context in the most general terms means "a mechanism for ensuring political communication based on the use of network computer technologies that promote an implementation of the principles of democracy and allows bringing the political structure into line with the real needs of the emerging information society" [2].

I consider E-democracy has certain disadvantages, such as vulnerability to manipulation by hackers who aim to extract various information. This risk arises from the lack of sufficient data protection. In addition, there is a possibility of rigging the results of polls and votes by the government apparatus. It is also possible to bribe certain segments of the population to form a false public opinion. And, since not all segments of society have access to the Internet, there is a danger of dividing it into citizens who have information and those who do not.

The spread and accessibility of ICT is a prerequisite for the democratization of society, the development of civic initiatives, and self-organization of people. Being the most important means of communication, ICTs are used to inform citizens on a wide range of issues of various types of life, to discuss bills and other legal acts in the process of preparing and formulating political decisions. Internet-based communication has reached a new level of its development, and it is necessary for the authorities in the first place.

The legal regulation of the right to the freedom of speech on the Internet is associated with a huge number of problems since in many cases there is a very real threat of increasing pressure on public opinion, the introduction of censorship, as well as falsification of facts by the state, violation of human rights to access reliable information. Such overly strict legal regulations that completely exclude freedom of speech and expression should not be allowed, as is the case in some states.

Everyone has the right to participate in the life of the information society, therefore, states are obliged to guarantee citizens access to the Internet. Moreover, strategies for regulating Internet access should be consistent with the requirements of article 19 of the Universal Declaration of Human Rights [3], as well as article 19 of the International Covenant on Civil and Political Rights [4] and (where appropriate) article 10 of the European Convention on Human Rights [5]. While certain countries and international organizations, such as the UN, may recognize access to the Internet as an integral part of the right to freedom of expression and, in fact, as a fundamental and universal right, a number of states are considering taking measures to block content and access. Finland and Estonia, for example, have ruled that access to the Internet is a fundamental right of their citizens. According to a 2010 BBC World Service survey of 27,000 people from 26 countries, "almost fourfifths consider access to the Internet as a fundamental right.' [6]

Moreover, a number of sites were banned in 2017 in Ukraine in connection with military events in the east of Ukraine, by a presidential decree on the introduction of new sanctions against Russia. The decision led to the ban of the resources in Ukraine of the Russian holding Mail.Ru Group, Yandex, social networks Odnoklassniki and Vkontakte and others. In May 2020, the same restrictions were reintroduced by Decree No. 184/2020 [7]. According to the international human rights organization Freedom House, blocking sites limited the rights of Ukrainians and causes significant damage to freedom of speech, information space and the country's economic interests. Representatives of the organization note that Ukrainians have not completely lost access to blocked websites and use a VPN. But we should understand that misinformation and propaganda materials are also posted on other social networks, in particular Facebook and Twitter, but they are not blocked for Ukrainians.

Real practice shows that even western democracies cannot do without some form of control over the Internet. Today, there are almost no states in the world that have completely abandoned Network regulation. Somewhere this is done openly, as in China. Access to the number of foreign websites from the territory of the People's Republic of China is limited under the Golden Shield project (the so-called Great Chinese Firewall). Web pages are filtered by keywords related to state security, as well as by the "black list" of website addresses. In other countries, under child protection laws or liability for spam and viral content, as in the United States. In any case, the Internet is actively censored everywhere. The difference is only related to the degree of state intervention.

I agree with Magomedov A.A. who considers that on the one hand, network technologies today allow us to talk about a new stage in the development of democracy [8]. Using the technical capabilities of the Internet and social networks (for example, Internet voting or Twitter), an active population can be involved in political decision making, forming both a system of truly popular control over the activities of politicians and government officials and the opposition movement. The development of such technologies indicates that modern society has already matured in order to independently express their civic position. On the other hand, it cannot be ruled out that these movements can be guided by a specific customer or manipulator, raising the question of the true causes of such pseudo-democracy.

\section{Conclusions}

One of the foundations of democracy is freedom of speech and freedom of political choice. In turn, the Internet is a platform for the implementation of these rights.

In democratic societies, the Internet is free from state regulation, often through its citizens criticize some government measures that reduce the social standard of living of people, restricting their rights and freedoms. In these actions, politics is seen - the interests of certain, opposition-minded political forces, oligarchic groups, political parties and movements that have access to the network.

The Internet has great potential for active influence not only on citizens' perceptions of certain political phenomena and events but also on their attitude to politics as a whole. Both the political passivity of the population in any issue, and its massive activity are directly related to the position of active bloggers and administrators of the sites most popular in this matter. Information support is one of the most important guarantees of the systematic and correct formation of the country's strategic course. I consider that the role of the Internet is to help citizens integrate into the process of forming government bodies, to acquire and implement skills of open political participation in the life of the state. 


\section{REFERENCES}

1. Yury Kabanov, Bogdan Romanov «Interaction between the Internet and the Political Regime: An Empirical Study (1995-2015)» p.282-291 URL: https://link.springer.com/chapter/10.1007\%2F978-3-319-69784-0 24

2. Grachev M.N., Madatov A.S. «Democracy: research methodology, perspective analysis.» M, 2004. P. 93.

3. Universal Declaration of Human Rights 1948 URL: https://www.un.org/ru/universal-declaration-human-rights/

4. International Covenant on Civil and Political Rights 1966 URL: https://www.ohchr.org/en/professionalinterest/pages/ccpr.aspx

5. European Convention on Human Rights 1950 URL: https://www.echr.coe.int/Documents/Convention_ENG.pdf

6. BBC News, Internet access is a "fundamental right" March 8, 2010 URL: http://news.bbc.co.uk/2/hi/8548190.stm

7. DECREE President of Ukraine On the decision of the National Security and Defense Council of Ukraine of May 14, 2020 "On the application, abolition and amendment of personal special economic and other restrictive measures (sanctions)" URL: https://zakon.rada.gov.ua/ laws/show/184/2020

8. Magomedov A.A. «Internet and politics: a crisis of the modern democracy or its new breath?» p.30-34 URL: https://cyberleninka.ru/ article/n/internet-i-politika-krizis-ili-novoe-dyhanie-sovremennoy-demokratii/viewer

9. Howard Rheingold «How Will The Internet influence Democracy?» URL: https://www.edge.org/response-detail/11618

10. Jan A.G.M. van Dijk, Kenneth L. Hacker «Internet and Democracy in the Network Society» 30 May 2018 URL: https://doi. org/10.4324/9781351110716

11. Stephen Coleman «Can The Internet Strengthen Democracy?» Polity Press Ltd., Cambridge, 2017 URL: https://www.litres.ru/stivenkoulman/mozhet-li-internet-ukrepit-demokratiu/chitat-onlayn/ 